\title{
A Study of Vowel Nasalization and Vowel Epenthesis Processes in Cameroon Francophone English
}

\author{
Gilbert Tagne Safotso* \\ Department of English, University of Maroua, Cameroon \\ Corresponding Author: Gilbert Tagne Safotso, E-mail: gilbertsafotso@gmail.com
}

\begin{abstract}
ARTICLE INFO
Article history

Received: November 18, 2017

Accepted: January 21, 2018

Published: March 01, 2018

Volume: 7 Issue: 2

Advance access: February 2018

Conflicts of interest: None

Funding: None

ABSTRACT

Unlike Cameroon English and Received Pronunciation, Cameroon Francophone English has a number of nasal and epenthetic vowels. Those nasal vowels are generally French ones, as Cameroon Francophone English is heavily influenced by that language. The epenthetic vowels found in Cameroon Francophone English as in many other non-native Englishes are difficult to explain. Part of the data analysed is drawn from past studies (Safotso 2001, 2006, 2012 \& 2015; Kouega 2008). This is complemented by the oral reading of some test words by French-speaking Cameroonian undergraduate/postgraduate students and some speech gathered from debates and interventions on various national TV channels and radio stations. Results show that in Cameroon Francophone English, vowel nasalization and vowel epenthesis occur in specific positions. This paper attempts to show how they operate in that variety of English.
\end{abstract}

Key words: Vowel, Nasalization, Epenthesis, Cameroon Francophone English, Processes, Variety

\section{INTRODUCTION}

In the growing world of New Englishes many studies generally limit themselves to segmental analysis (Hung 2000; Gargesh 2004; Gut 2007). Indeed, unlike other levels of analysis such as that of rhythm, intonation, grammar or vocabulary, the study of the consonants and vowels of any language is quite easy. Yet, at supra-segmental level, many languages reveal very interesting features that can be analysed for a better understanding of their functioning. Unfortunately, in the literature, there are for example very few studies on the rhythm and intonation of nonnative Englishes (Diez 2005; Vicenk \& Sundara 2013; Fuchs 2016). Those features are, however, some of their salient characteristics. The segmental analysis of any non-native variety of English just has to be the foundation for its in-depth investigation. Early studies (Kouega 2008; Safotso 2001 \& 2015) on CamFE (Cameroon Francophone English) revealed that vowel nasalization and vowel epenthesis are some of its striking supra-segmental features. Those two features which hamper its intelligibility to native speakers and speakers of other New Englishes, and which are so stable, are a problem which necessitates an in-depth investigation. A close analysis of that phenomenon would better through some light on its functioning. This study therefore aims to look into the vowel nasalization and vowel epenthesis processes in Cameroon Francophone English, which are two aspects of that variety of English so far not fully explored.

\section{REVIEW OF SOME LITERATURE ON CAMEROON FRANCOPHONE ENGLISH}

Spoken by French-speaking Cameroonians, who for some two decades now have drastically changed their attitude toward English, CamFE (Cameroon Francophone English) has its stable phonological features which differentiate it from RP (Received Pronunciation), CamE (Cameroon English) and other New Englishes. Some features of CamFE have been studied by Safotso (2001, 2006, 2012 \& 2015) and Kouega (2008), and clearly show that it is a new variety of English in its own right. Other works on different aspects of this variety of English include Simo Bobda (2013), Atechi (2015) and Safotso (2016). Those studies respectively discuss the emergence and the standardisation of CamFE, its implication on the future of English in Cameroon, and its atypical evolution with regard to existing models. Simo Bobda remarks that, having been long denied status as a legitimate accent of English in Cameroon by scholars, CamFE pronunciation is fast emerging onto the officially English-French bilingual landscape. Its accent is introduced into the classroom by the very teachers produced in highly rated teacher training institutions (Simo Bobda 2013: 289). Atechi (2015: 25) notes that there is now a large number of CamFE speakers teaching English both as a second and a foreign language in secondary schools and at tertiary level across the country, which contributes in spreading its accent to all the corners of Cameroon. As to which variety between Cameroon Francophone English and Cameroon English will influence the other or take the lead in future, Atechi remains very cautious, because of the complex linguistic landscape of Cameroon and the changes that are taking place in it. Safotso (2016) studied the evolution process of CamFE to show that it is an atypical example to Moag's (1992) and Schneider's (2003, 2007 \& 2009) models. All the studies reviewed above testify to the dynamism of CamFE in Cameroon. Section 2 below looks at the method of data collection. 


\section{METHODOLOGY}

The data analysed partly come from past studies (Safotso 2001, 2006, 2012, 2015; Kouega 2008) and from the oral reading of some test words by some Frenchspeaking undergraduate/ postgraduate students of the

Departments of English and Bilingual studies of the University of Maroua $(\mathrm{N}=40)$. The Test words for vowel nasalization consisted in a corpus of 80 words containing the sequences -imp, -imp, -emb, -emp, -ent,-enk, etc. for / $\tilde{\varepsilon} /$; - -ant, -ang, -enc, -env, etc. for / $\tilde{\mathbf{a}} /$, and -on, -ond, -ount, ound, etc. for $/ \tilde{\mathrm{\jmath}} /$. The test words for vowel epenthesis were made up of 35 words containing the sequences -vel, -nel, ble, -dle, etc. for $/ \varepsilon /$; -ple, -ble, -gle for $/ \mathrm{s} /$, and -se, -s (in medial and final positions) for $/ \mathrm{\partial} /$. This was complemented by some free speech gathered on university campus and from debates and interventions of French-speaking leaders and politicians on various TV channels and radio stations around Cameroon. The section which follows examines how vowel nasalization functions in CamFE.

\section{VOWEL NASALIZATION PROCESSES IN CAMEROON FRANCOPHONE ENGLISH}

CamFE has 12 monophthongs like RP, but with a number of different segments. Cameroon English has only eight (see Safotso 2015:448). These are CamFE monophthongs: / i, $\varepsilon, \tilde{\varepsilon}$, e, a, ã , ॰, o, 乞̃, u y, ə /. They comprise the nasal vowels / $\tilde{\varepsilon}, \tilde{\mathrm{a}}$, $\tilde{\jmath}$ / which are not attested in RP (Received Pronunciation) but in French. This feature of CamFE is quite stable, and has been identified by a number of previous studies (Safotso 2001, 2006, 2012, 2015; Kouega 2008). Those studies mostly identified the feature without getting into an in-depth analysis of its working processes. Kouega (2008: 116) notes that / $\tilde{\varepsilon} /$ tends to occur where RP /In/ is expected; / $\tilde{\boldsymbol{a}} /$ is heard where / $\varepsilon n / /$ is expected, usually where the letters 'en' are present, and / $\tilde{\mathrm{o}}$ / tends to occur where the sequence 'on' or 'oun' is present. This is a simplistic way of viewing the complex phenomena that the nasalization of / $\varepsilon, \mathrm{a}, \mathrm{o} / \mathrm{in} \mathrm{CamFE}$ entails. CamFE speakers nasalize $/ \varepsilon /$ in many contexts as shown in Table 1.

Table 1. Contexts where / $\tilde{\varepsilon} /$ occurs in CamFE

\begin{tabular}{|c|c|c|c|}
\hline Example word & Portion spelling & CamFE form & RP form \\
\hline Import & IMP & $\tilde{\varepsilon}$ pot & Impo:t \\
\hline Impulsively & IMP & Eppylsivli & Imp $\Lambda$ lsivli \\
\hline$\underline{\text { Imbecile }}$ & IMB & $\tilde{\varepsilon}$ besil & Imbisi:1 \\
\hline Employer & EMP & $\tilde{\varepsilon} \mathrm{pl} \varepsilon \varepsilon$ & Impləıว \\
\hline Emperor & EMP & $\tilde{\varepsilon}$ pero & empərə \\
\hline$\underline{\text { Embrace }}$ & EMB & $\tilde{\varepsilon}$ bres & Imbreis \\
\hline Embassy & EMB & $\tilde{\varepsilon}$ basi & عmbəsi \\
\hline Entrance & ENT & $\tilde{\varepsilon} \operatorname{tr} \tilde{\boldsymbol{a}} \mathrm{S}$ & Intrəns \\
\hline frequently & ENT & frekwẽli & frıkwənlı \\
\hline Encouraged & ENK & ع̃kurez & Ink $\Lambda \mathrm{rId} 3 \mathrm{~d}$ \\
\hline Encounter & ENK & $\tilde{\varepsilon} \mathrm{k} \tilde{\mathrm{t}} \mathrm{t}$ & Inkauntə \\
\hline Expensive & ENS & ekspẽsiv & IkspensıV \\
\hline providence & ENS & provd $\tilde{\varepsilon} s$ & providəns \\
\hline Envelope & ENV & $\tilde{\varepsilon}$ vələp & Envələup \\
\hline Environment & ENV & $\tilde{\varepsilon} \operatorname{var} \tilde{m} \mathrm{~m} \tilde{\varepsilon}$ & InvaIrənmənt \\
\hline Enlarge & ENL & Ẽla3 & Inla:d3 \\
\hline$\underline{\text { Enlist }}$ & ENL & $\tilde{\varepsilon}$ list & Inlist \\
\hline Enrich & ENR & $\tilde{\varepsilon}$ rif & Inrits \\
\hline Enrol & ENR & $\tilde{\varepsilon} \mathrm{rol}$ & Inrəul \\
\hline Province & INS & provẽs & provins \\
\hline Instance & INS & $\tilde{\varepsilon} \mathrm{st} \tilde{a} \mathrm{~S}$ & Instəns \\
\hline provincial & INC & $\operatorname{prov} \tilde{\varepsilon} \int \mathrm{al}$ & prəvinfəl \\
\hline Incident & INC & $\tilde{\varepsilon} \operatorname{sid} \tilde{\varepsilon}$ & Insidənt \\
\hline
\end{tabular}




\begin{tabular}{|c|c|c|c|}
\hline Inferior & INF & $\tilde{\varepsilon}$ ferio & Infiərıə \\
\hline$\overline{\text { Infection }}$ & INF & $\tilde{\varepsilon} f \varepsilon k \int \tilde{\jmath}$ & Inf $\varepsilon \mathrm{k} \int \partial \mathrm{n}$ \\
\hline Interest & INT & $\tilde{\varepsilon} \operatorname{tr} \varepsilon S$ & Intrist \\
\hline$\overline{\text { intact }}$ & INT & ctak & Intækt \\
\hline
\end{tabular}

Table 1 shows that $/ \tilde{\varepsilon} /$ occurs in many contexts in CamFE. Kouega (2008 :116) remarks that it occurs where RP/In/ is expected. This can be verified in many words, e.g. instance, inferior,

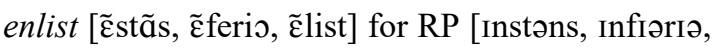
Inlist]. There are many other contexts where $/ \tilde{\varepsilon} /$ occurs in CamFE. It replaces RP / $\mathrm{\varepsilon n} /, / \mathrm{Im} /, / \varepsilon \mathrm{m} /$, / ən/, e.g. expensive, envelope, import, imbecile, emperor, frequently, providence

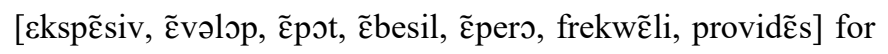

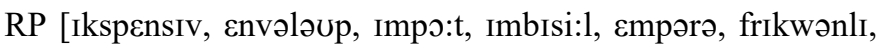
providəns]. In spelling, there are also many contexts where / $\tilde{\varepsilon}$ / happens in CamFE. It generally occurs when the portion of the word is spelt with '-imp-, - imb-, -emp-,- emb-, -ent-, enk-, -ens-, -env-,- enl-, -enr-, -ins-, -inc-, -inf-, -int-', as highlighted in the table above. It can also be remarked that in most words, this takes place in initial position. Table 2 lists the contexts where / $\tilde{\mathrm{a}}$ / occurs in CamFE.

Table 2. Contexts where / $\tilde{\mathbf{a}} /$ occurs in CamFE

\begin{tabular}{|c|c|c|c|}
\hline Example word & Portion spelling & CamFE form & RP form \\
\hline Tyrant & ANT & tirã & taiərənt \\
\hline Important & ANT & epotã & Impo:tənt \\
\hline Mangoes & ANG & mãgo & mæygəuz \\
\hline Ganglion & ANG & gãgliõ & gæygliən \\
\hline Mandate & AND & mãdet & mændeIt \\
\hline Landing & AND & lãdin & lændıy \\
\hline Difference & ENC & difərãs & difərəns \\
\hline Eminence & $\mathrm{ENC}$ & eminãs & Eminəns \\
\hline Relentlessly & ENT & relãlesli & rilentlisli \\
\hline Pentecostal & ENT & pãtekostal & pentikpstl \\
\hline Henry & ENR & ãri & henrI \\
\hline Enrage & ENR & ãra3 & InreId3 \\
\hline Envoy & ENV & $\tilde{a} v o i$ & EnvวI \\
\hline
\end{tabular}

As with $/ \tilde{\varepsilon} /$, in CamFE, there are many contexts where / $\tilde{\mathbf{a}} /$ is heard. It generally occurs as a substitute for RP /ən/, /æn/, /æn/, /عn/, /In/, e.g. tyrant, important [tirã, \&potã ] for RP [taiərənt, Impo:tənt]; bank, mangoes [bãk, mãgo] for RP [bæyk, mæygəu]; landing, mandate [lãdin, mãdet] for RP [lændı̄, lændın]; Henry [ãri] for RP [henrI]; encourage, enrage [ãkura3, ãra3] for RP [InkırId3, InreId3]. In spelling, the concerned portions generally are '-ant-, -ang-, -and-, -enc-, -ent-, -enr-,, -env-, -enk-.'. It should be noted that for certain words, the choice of the realisation of the portion is between $/ \tilde{\varepsilon} /$ and / $\tilde{\mathrm{a}} /$, especially when it is spelt with 'EN' or 'AN', e.g.

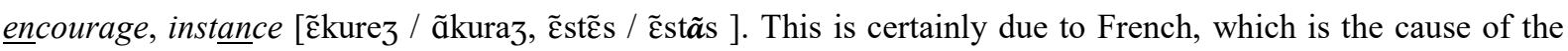
nasalization of the half-open front vowel / $\varepsilon /$ here. Indeed, in French, depending on the word, 'EN' and 'AN' are

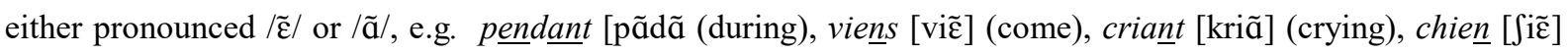
(dog). Table 3 illustrates the nasalization processes of $/ \mathrm{\jmath} /$ in CamFE.

Table 3. Contexts where / $/$ / occurs in CamFE

\begin{tabular}{|c|c|c|c|}
\hline Example word & Portion spelling & CamFE version & $\mathrm{RP}$ version \\
\hline Contribution & ONT & 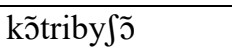 & 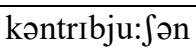 \\
\hline Control & ONT & kõtrol & kəntrəul \\
\hline Country & OUNT & kõtri & kıntrI \\
\hline Counting & OUNT & kõtin & kauntın \\
\hline Boundary & OUND & bõdari & baundərI \\
\hline Pounded & OUND & põd $\varepsilon d$ & paundid \\
\hline
\end{tabular}




\begin{tabular}{|c|c|c|c|}
\hline Conclusion & ONC & kõklyz̃̃ & kənklu:zən \\
\hline Concrete & $\mathrm{ONC}$ & kõkrit & kənkrkit \\
\hline Monday & OND & mõde & $\mathrm{m} \wedge \mathrm{ndI}$ \\
\hline Condom & OND & kว̃dom & kpndəm \\
\hline Construct & ONS & kõstrok & kənstrıkt \\
\hline Demonstrate & ONS & demõnstret & demənstreit \\
\hline Convoy & ONV & k̃̃voi & kpnvəI \\
\hline Conversion & ONV & $\operatorname{kov} \varepsilon \int \tilde{\jmath}$ & 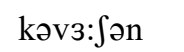 \\
\hline Son & ON & s̃̃ & $\mathrm{s} \Lambda \mathrm{n}$ \\
\hline Electron & $\mathrm{ON}$ & elektrõ & Ilektron \\
\hline Long & ONG & $1 \tilde{5}$ & $\log$ \\
\hline Gong & ONG & g̃ & gon \\
\hline Conference & ONF & kõferens & kpnfərəns \\
\hline Confuse & ONF & kõfyz & kənfju:z \\
\hline
\end{tabular}

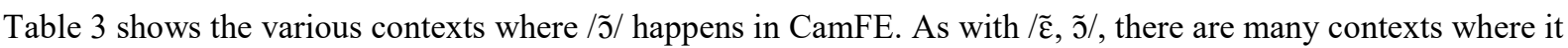
occurs. It genẽrally happens in replacement of RP $/ \mathrm{on} /, / \mathrm{An} /, / \mathrm{av} /, / \mathrm{pn} /, / \mathrm{py} /$, as in the following examples from

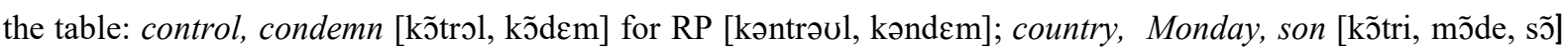

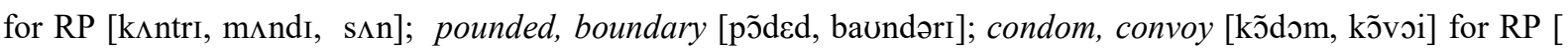

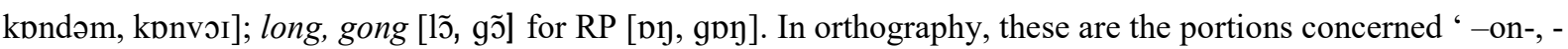
ont-, -ount-,- ound-, -onc-, -ond-, -ons-, -onv-, -ong-, -onf-'. As a general rule, it can be observed that -ON- and -OUN- are pronounced / $\tilde{\mathrm{J}} /$ in CamFE (see Safotso 2015: 384). If the pronunciation of $-\mathrm{ON}$ - as $/ \tilde{\mathrm{J}} / \mathrm{can}$ be attributed to French, that of-OUN- has no explanation, as such combination does not exist in that language. The next section analyses the vowel epenthesis processes.

\section{VOWEL EPENTHESIS PROCESSES IN CAMEROON FRANCOPHONE ENGLISH}

In RP, Roach (1991: 79-83) mentions / 1, n, m, y, r / as syllabic consonants. A syllabic consonant is one which stands at the centre of the syllable in the absence of a vowel element as in pedal, sadden, history [ pedl, sædn, histri ]. In non-native Englishes, the epenthesized vowel is generally inserted before those consonants. Simo Bobda (1994: 25-28) reviewed a number of New Englishes in which this phenomenon occurs. They include Indian English (Platt et al. 1984), Malaysian English (Wong 1982), East African English (Hancock 1984), West African English (Todd 1984), South Asian English (Kachru 1984 \& 1986). For Example, in Indian English, glass and play are pronounced [gəlas, pəlai] for RP [gla:s, pleI] (Platt et al. 1984: 43); in South Asian English, school and station are pronounced [iskul, iste $\left.\int a n\right]$ for RP [sku:1, sterJən]. Tables 4, 5, 6, and 7 show some contexts where vowel epenthesis occurs in CamFE.

Table 4. Contexts where / $\varepsilon /$ occurs as epenthetic vowel in CamFE

\begin{tabular}{|c|c|c|c|}
\hline Example word & Portion spelling & CamFE version & RP version \\
\hline Travel & VEL & travel & trævl/trævəl \\
\hline Colonel & NEL & kolonel & k3::nl /k3::nəl \\
\hline Novel & VEL & novel & npvl /npvəl \\
\hline Camel & MEL & $\operatorname{kam} \varepsilon 1$ & kæml / kæməl \\
\hline Parcel & CEL & pasel & pa:sl / pa:səl \\
\hline Panel & NEL & panel & pænl / pænəl \\
\hline Able & BLE & ebcl & eibl /eıbəl \\
\hline Table & BLE & tebel & terbl /terbəl \\
\hline Temple & PLE & tempel & tধmpl /t\&mpəl \\
\hline Paddle & DLE & padel & pædl /pædəl \\
\hline Mingle & GLE & $\operatorname{ming} \varepsilon 1$ & mingl / mingal \\
\hline Ankle] & KLE & ãkel & æjkl /æりkəl \\
\hline Sizzle & ZLE & sizel & sIzl / sızəl \\
\hline Castle & TLE & kastel & kæstl / kæstəl \\
\hline Wednesday & ES & wednesde & wenzdi \\
\hline
\end{tabular}


In Table 4, it can be observed that / $/$ / generally occurs as epenthetic vowel in CamFE in the word penultimate position where RP/o/ is optionally expected followed by $/ 1 /$, as in saddle, constable [sadel, kõstebel ] for RP [sædl / sædəl , kınstəbl / kınstəbəl]. In connected speech, it would happen where the syllabic $/ 1 /$ is expected. This feature is also observable in CamE (Cameroon English).
In orthography, the portions concerned are: '-vel, -nel, mel, -cel, -ble, -ple, -dle, -gle, -kle, -zle, -tle'. The insertion of the epenthetic $/ \varepsilon /$ in Wednesday [wednesde] for RP [wenzdi] follows no particular rule, and can be attributed to spelling pronunciation. Table 5 lists the contexts where $/ \mathrm{o} /$ occurs as epenthetic vowel in CamFE.

Table 5. Contexts where / $/ \mathbf{0}$ occurs as epenthetic vowel in CamFE

\begin{tabular}{|c|c|c|c|}
\hline Example word & Portion spelling & CamFE version & RP version \\
\hline People & PLE & pipol & Pi:pl /pi:pəl \\
\hline Temple & PLE & tempol & templ /tempəl \\
\hline Table & BLE & tebol & terbl/teibəl \\
\hline Able & BLE & ebol & eıbl /eıbəl \\
\hline Needle & DLE & nidol & ni:dl/ ni:dəl \\
\hline Cradle & DLE & kredol & kreıdl/ kreıdəl \\
\hline Pimple & PLE & pimpol & pImpl/ pImpəl \\
\hline Mingle & GLE & mingol & $\mathrm{mingl} / \mathrm{ming}$ \\
\hline
\end{tabular}

As with / $\varepsilon /$ studied in Table 4, in CamFE, / $/$ / occurs as epenthetic vowel in the word penultimate position where / $/$ / is optionally expected followed by $/ 1 /$. What determines the choice between $/ \varepsilon /$ and $/ 0 /$ is hard to find. But in spelling, it can be remarked that the choice operates only when the portions concerned are '-ple, ble, -gle', e.g. temple, able, mingle [tempel / tempol, ebel / ebol, mingel / mingol] for RP [templ /tempəl, eibl /eibəl, mingl/ mingəl. In orthography, '-dle' is another portion of the word where $/ \mathrm{\rho} /$ operates as epenthetic vowel. In CamFE, /o/ is also one of the epenthetic vowels. Some of the contexts where it takes place are shown in Table 6.

Table 6. Contexts where /a/ occurs as epenthetic vowel in CamFE

\begin{tabular}{|c|c|c|c|}
\hline Example word & Portion spelling & CamFE version & RP version \\
\hline Has & $\mathrm{S}$ & hazə & hæz \\
\hline Was & $\mathrm{S}$ & WOZə & WDZ \\
\hline I $\underline{s}$ & S & izə & IZ \\
\hline Does & S & dozə & $d_{\Lambda} \mathrm{z}$ \\
\hline Summarise & SE & somarazə & $\mathrm{s} \Lambda \mathrm{m} \partial \mathrm{raIz}$ \\
\hline Sensitize & ZE & sãsitazə & sensitaiz \\
\hline Because & SE & bikoze & bikpz \\
\hline Must & ST & məsə & $\mathrm{m} \Lambda \mathrm{st}$ \\
\hline Have & VE & avə & hæv \\
\hline And & $\mathrm{D}$ & andə & ænd \\
\hline But & $\mathrm{T}$ & boto & $\mathrm{b} \Lambda \mathrm{t}$ \\
\hline
\end{tabular}

It can be observed that $/ \partial /$ takes place as epenthetic vowel in final position of certain words. It is one of the peculiar features of CamFE. It happens where nothing is expected in RP. It can be remarked that this generally happens after/z/ in final position, e.g. has, because [haz ə, bikoze] for RP [hæz, bikpz], but it can also be observed with other words such as and, but. Cameroon French, that the speakers of CamFE speak, is certainly the cause of this problem which is not observed in CamE.
Indeed, in Cameroon French, the letter E, which normally is silent in final position of words in native French, is articulated, e.g. patate (potato), mange (eat), assiette (plate) [patatə, mãzə, asictə]* for native French [patat, mãz, asict]. So, the few cases listed above are just indicative, as the epenthetic /ə/ in final position can occur with any word in CamFE. Table 7 looks at the contexts where /ia/ operates as epenthetic vowel.

Table 7. Contexts where / ia/ occurs as epenthetic vowel in CamFE

\begin{tabular}{|c|c|c|c|}
\hline Example word & Portion spelling & CamFE version & RP version \\
\hline Spatial & IAL & spasial & speifl/speifəl \\
\hline Essential & IAL & es $\tilde{\varepsilon}$ sial & Isen $\int 1$ /Isen $\int \partial l$ \\
\hline Commercial & IAL & komesial & 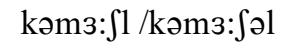 \\
\hline Special & IAL & spesial & speIf1/spei $\int ə l$ \\
\hline Credential & IAL & kred $\tilde{\varepsilon}$ sial & krIden $\int 1 / k r I d \varepsilon n \int \partial l$ \\
\hline
\end{tabular}


/ia/ is a CamFE and CamE diphthong, e.g. Asia, India [esia, india] for RP [eISe, Indiə] (Safotso 2015: 449). It occurs as epenthetic vowel before the final RP / $1 /$ al /. This is certainly induced by spelling, as the portion concerned is ial- as shown in the table above. This feature is not particular to CamFE, but is also present in CamE.

\section{CONCLUSION}

In short, vowel nasalization and vowel epenthesis are two of the salient features of CamFE. Their processes are quite complex. There are many contexts where they take place in that variety of English. Those contexts are consistent and predictable, and can give room for some generalisations. If the vowel nasalization can generally be attributed to French as all the vowels concerned are attested in it, the cause of the insertion of the epenthetic vowels is hard to find. Nevertheless, since the epenthetic vowels like the nasalized vowels do not occur haphazardly in CamFE, this paper has thrown some more light on the functioning of those aspects of that variety of New Englishes.

\section{REFERENCES}

Atechi, S. N. (2015). The Emergence of Cameroon Francophone English and the Future of English in Cameroon. Journal of English Linguistics, 3 (3), 23-33.

Diez, F. G. (2005). Intonation Focus in the Interlanguage of a Group of Spanish Learners of English. Revista Alicantina de Estudios Ingleses 18, 129-147.

Fuchs, R. (2016). Speech rhythm in varieties of English: Evidence from educated Indian English and British English. Singapore: Springer \& Sciense Business Media.

Gargesh, R. (2004). Indian English: Phonology. In Kortman, B et al. eds.(2004), A Handbook of Varieties of English, Vol. 1: Phonology. Berlin: Mouton de Gruyter, pp. 992-1002.

Gut, U. (2007). First Language Influence and Final Consonant Clusters in the new Englishesof Singapore and Nigeria. World Englishes, 6 (3), 346-359. http://dx.doi. org/10.1111/j.1467-971X.2007.00513.x

Hung, T. T. N. (2000). Towards a phonology of Hong Kong English. World Englishes, 19 (3), 337-356. Doi: 10.1111/1467-971X.00183

Hancock, I. F. (1984). English in East Africa. In Bailey, R.W. \& Gorlach, M. eds. (1984), English as a World Language. Michigan: The University of Michigan Press, pp. 306-323.

Kachru, B.B. (1984). South East Asian English. In Bailey, R. W. \& Gorlach, M.eds. (1984), pp. 353-382.

Kachru, B.B. (1986). The Alchemy of English: the Spread, Functions and Models of Non-Native Englishes. Oxford: Pergamon Press.

Kouega, J. P. (2008). The English of Francophone Users in Cameroon: A Phonological Appraisal. Annals of the Faculty of Arts, Letters and Social Sciences, University of Yaounde I. Special Edition. Festschrift in Honour of Professor Paul N. Mbangwana,109-120.
Moag, R. F. (1992). The Life Cycle of Non-Native Englishes: A Case Study. In Kachru, B. B. ed. (1992), The Other Tongue-English across Cultures., $2^{\text {nd }}$ ed. Urbana \& Chicago:University of Illinois Press.

Platt, J. (1984). English in Singapore, Malaysia and Hongkong. In Bailey, R. W. \& Gorlach, M. eds. (1984), pp. 383-414.

Roach, P. (1991). English Phonetics and Phonology-A Practical Course. Cambridge: Cambridge University Press.

Safotso, G.T. (2001). Impact of French and some Local Languages on English Pronunciation in Cameroon-Pedagogical Implications: A Case Study of of Yémba and Ghoma'la' Languages, Unpublished MA Dissertation,Universty of Leicester.

Safotso, G. T. (2006). The Pronunciation Problems of Ghoma'la'-French and Ewondo-French Speaking Learners of English and Pedagogical Inpications, PhD Research Project,University of Yaounde I.

Safotso, G. T. (2012). Aspects of Cameroon Francophone English (CamFE) Phonology.Theory and Practice in Language Studies, 2 (12), 2471-2477.

Safotso, G. T. (2015). A Study of the Phonological Features of Cameroon Francophone English. Saabrüncken: Scholars' Press.

Safotso, G. T. (2016). Cameroon Francophone English: An Atypical Example to Moag's and Schneider's Models. British Journal of English Linguistics, 4 (5), 1-10.

Schneider, E. W. (2003). The Dynamic of New Englishes: from identity construction to Dialect birth. Language, 79, 233-281.

Schneider, E. W. (2007). Postcolonial Englishes. Varieties around the World. Cambridge/Cambridge University Press.

Schneider, E, W. (2009). Towards Endonormativity? African English and the Dynamic modelof the Evolution of Postcolonial Englishes. In Harrow, K. and Mpoche, K. eds. (2009).Language, Literature and Education in Multicultural Societies: Collaborative Research on Africa. Cambridge: Cambridge Scholars Publishing.

Simo Bobda (1994). Aspects of Cameroon English Phonology. Bern: Peter Lang.

Simo Bobda (2013). The Emergence of a Standardizing Cameroon Francophone English Prounciation in Cameroon. In Nils-Lennard Johannesson et al. ed. (2013), of Butterflies and birds, of dialects and genres. Stockholm: US-AB, pp. 289-301.

Todd, L. (1984). The English Language in West Africa. In Baley, R. W. \& Gorlach, M eds.(1984), pp.281-305.

Vicenik, C. \& Megha, S. (2013). The role of Intonation in language dialect discrimination by adults. Journal of Phonetics 41, 297-316.

Wong, I. (1982). Native Speaker English for the Third World Today. In Pride, J. ed. (1984),New Englishes. Rouley: Newbury house Publishing, pp. 261-286. 